Assiut University web-site: $\underline{w w w . a u n} . e d u . e g$

\title{
VIRULENCE GENES OF LISTERIA MONOCYTOGENES ISOLATED FROM SOME READY-TO-EAT CHICKEN MEALS
}

\author{
SOHAILA, F.H. EL-HAWARY ${ }^{1}$, MOHAMED, H. MOHAMED ${ }^{2}$ and SAYED, H. AL-HABATY ${ }^{3}$ \\ 1,2 Department of Food Hygiene, Animal Health Research Institute, Agriculture Research Center, Assiut Provincial Lab. \\ ${ }^{3}$ Department of Bacteriology, Animal Health Research Institute, Agriculture Research Center, Assiut Provincial Lab.
}

Received: 30 September 2018; Accepted: 28 October 2018

\begin{abstract}
This study was conducted in Assiut, Egypt, to investigate the prevalence of Listeria monocytogenes in a total of 75 ready-to-eat (RTE) cooked chicken meals collected from different restaurants. All isolates were further examined for the virulence marker gene and antibiotic resistance genes. L. monocytogenes were isolated from $4(5.3 \%)$ of the samples analyzed, including $2(8 \%)$ of chicken shawerma, $1(4 \%)$ of chicken burger and $1(4 \%)$ of chicken breast fillet. All the recovered L. monocytogenes organisms were confirmed by PCR assay for the presence of $16 \mathrm{~S} r R N A$ gene and all of the tested isolates harboured this gene, among which $100 \%$ were revealed to incode inlA and inlB virulence genes. Whereas, all four (100\%) isolates of L. monocytogenes were found to harbor mefA gene (macrolides resistance gene) and Aad6 gene (aminoglycosides resistance gene). While, Kan gene (Kanamycin resistance gene), tetM gene (tetracycline resistance gene) and Cat gene (chloramphenicol resistance gene) couldn't be detected in any examined strains. These results signify the importance of sustained surveillance of L. monocytogenes in cooked chicken meat to minimize the risk of contamination and protecting consumers against outbreaks.
\end{abstract}

Key words: L. monocytogenes, virulence genes, RTE cooked chicken meals.

\section{INTRODUCTION}

Listeria monocytogenes has been recognized as an important opportunistic human pathogen since 1929 and as food borne pathogen since 1981 (Jeyasekaran et al., 1996). Ready-to-eat (RTE) meat products represent high risk to the consumers because they are usually cooked during manufacture and consumed without further heating, so cross contamination with food borne pathogens during the processing cannot be overcome (Goulet et al., 2008). The extended distribution throughout the food processing environment and asymptomatic human carriers (Wagner et al., 2005) and the psychrotrophic character of Listeria species appear to be the main causes of the prevalence in different kinds of refrigerated RTE meat products and contamination could occur either pre- or post-processing (Lianou and Sofos, 2007). Of the 20 RTE food categories evaluated by the Food and Drug Administration and the Food Safety and Inspection Service, deli meats were classified in the very high risk category to be the principal potential source of L. monocytogenes (FAO/WHO, 2004). In general, consumption of food contaminated with L. monocytogenes may cause listeriosis which may result in serious human illness with symptoms of septicemia, meningitis,

Corresponding author: MOHAMED, H. MOHAMED

E-mail address: sahlo172@yahoo.com

Present address: Department of Food Hygiene, Animal Health Research Institute, Assiut Provincial Lab. encephalitis and gastroenteritis particularly in children, the elderly and immunosuppressed individuals. It may also cause miscarriage in pregnant women (Blum-Menezes et al., 2013). L. monocytogenes had the second highest fatality rate $(20 \%)$ and the highest hospitalization rate $(90 \%)$ in virulence (Swaminathan, 2001). Multistate outbreaks of food borne listeriosis were recorded (Gottlieb et al., 2006).

In study conducted by Gusman et al. (2014), the prevalence of $L$. monocytogenes in examined samples of RTE foods was $1.97 \%$, and the count of L. monocytogenes in all positive samples exceeded the limit of 100 colony forming units (CFUs) per gram. According to the data reported by the (EFSA) European Food Safety Authority (2015), prevalence rate of L. monocytogenes in RTE foods was $4.4 \%$.

Multiple key virulence factors such as internalin (inlA), listeriolysin (hlyA), phosphatidylinositol phospholipase C (plcA), actin polymerization protein (actA) and invasive associated protein (iap) are important in L. monocytogenes pathogenesis (Furrer et al., 1991 and Portnoy et al., 1992). Therefore, detection of just one virulence associated gene by PCR is not always sufficient to identify L. monocytogenes (Nishibori et al., 1995). In addition, it is plausible that some $L$. monocytogenes strain may lack one or more virulence determinants because of spontaneous mutations (Cooray et al., 1994) 
L. monocytogenes is usually susceptible to a wide range of antibiotics, but in 1988 a multidrugresistant strain was found in France (PoyartSalmeron, 1990). Since then other strains resistant to one or more antibiotics have been recovered from food, the environment and from sporadic cases of human listeriosis (Conter et al., 2009). The occurrence of antibiotic resistance complicates therapy and lengthens convalescence from illness. Antibiotic use in clinical medicine (appropriate and otherwise) has contributed to the emergence of multidrug-resistant strains, but another contributor has been the use of antibiotics in animal feed as growth promoters (Harakeh et al., 2009). In 2013, based on the proposals issued by the European Food Safety Authority, the EU put forward and discussed with the member states a new legislation on the harmonized monitoring of antimicrobial resistance in Salmonella, Campylobacter and indicator bacteria in food-producing animals and food (EFSA, 2015), but there are relatively few epidemiological studies, and thus, only limited information on antibiotic resistance prevalence and spread concerning Listeria spp. Considering the high mortality rate of listeriosis in vulnerable populations, it is important to insure the effectiveness of antimicrobials and monitor the emergence of antimicrobial-resistant Listeria strains (Gómez et al., 2014).

The increase of RTE food consumption due to changes in the lifestyle and the ability of L. monocytogenes to attach to different surfaces forming biofilms and consequently its persistence in food environment necessitate periodically repeated surveys for determining the prevalence and the distribution of some virulence genes in L. monocytogenes isolated from RTE food and to evaluate the resistance genotype of isolated L. monocytogenes strains to selected antibiotics used for treating listeriosis.

\section{MATERIALS AND METHODS}

\section{Collection of samples:}

A total of 75samples of cooked RTE chicken meat ( 25 for each shawerma, burger and breast fillet) were collected during the period from October to December 2017 from different restaurants in Assiut province. The samples were collected hygienically in sterile plastic bags and transported to the laboratory in icebox within 2 to $4 \mathrm{~h}$.

Isolation and identification of $L$. monocytogenes: Listeria monocytogenes was isolated from RTE chicken meat samples following the procedure recommended by the International Organization for Standardization (ISO11290 -1, 2017). Briefly, a 25 g meat sample was aseptically homogenized in $225 \mathrm{ml}$ pre-enrichment half-Fraser broth (CM0895, Oxoid Ltd) supplemented with half-Fraser supplement (SR0166E, Oxoid Ltd) in Stomacher bags (Seward
Ltd, West Sussex, UK) for $30 \mathrm{~s}$ using a Stomacher circulator (Easy Mix, AES Laboratoire, Bruz, France), followed by incubation at $30^{\circ} \mathrm{C}$ for $24 \mathrm{~h}$. Then $0.1 \mathrm{ml}$ half-Fraser broth was added to $10 \mathrm{ml}$ Fraser broth containing Fraser supplement and incubated at $37^{\circ} \mathrm{C}$ for $48 \mathrm{~h}$. At the end of incubation, a loopful of Fraser broth was streaked on chromogenic Listeria agar (ALOA) supplemented with Brilliance Listeria Differential Supplement (SR0228E, Oxoid Ltd) and incubated at $35^{\circ} \mathrm{C}$ for 24 to $48 \mathrm{~h}$. L. monocytogenes appear as green-blue colonies surrounded by an opaque halo. For biochemical identification of L. monocytogenes, five suspect colonies from each plate were streaked on TSA (M290, Oxoid Ltd) supplemented by $(0.6 \%)$ yeast extract (LP0021) and incubated at $37^{\circ} \mathrm{C}$ for 18-24 h.

Biochemical confirmation of $L$. monocytogenes: Suspected colonies were verified by Gram staining, catalase, oxidase, haemolysis and CAMP tests, motility, Methyl Red-Voges Proskauer (MR-VP) reactions, nitrate reduction and the production of acids from rhamnose, xylose and mannitol for the identification as described by ISO11290 -1 (2017).

PCR assay for identification of $16 S \mathrm{rRNA}$, virulence genes and resistance genes of L. monocytogenes:-

The isolated L. monocytogenes strains were sent to the Reference laboratory for veterinary Quality Control of poultry production in Animal Health Research Institute, Dokki, Giza, Egypt, for identification of $16 \mathrm{~S} r R N A$, virulence genes and resistance genes of $L$. monocytogenes as follow:

\section{DNA extraction:}

DNA extraction from samples was performed using the QIAamp DNA Mini kit (Qiagen, Germany, $\mathrm{GmbH}$ ) with modifications from the manufacturer's recommendations. Briefly, $200 \mu \mathrm{l}$ of the sample suspension was incubated with $20 \mu$ l of proteinase $\mathrm{K}$ and $200 \mu \mathrm{l}$ of lysis buffer at $56^{\circ} \mathrm{C}$ for $10 \mathrm{~min}$. After incubation, $200 \mu 1$ of $100 \%$ ethanol was added to the lysate. The sample was then washed and centrifuged following the manufacturer's recommendations. Nucleic acid was eluted with $100 \mu$ l of elution buffer provided in the kit.

\section{Oligonucleotide Primer:}

Primers used were supplied from Metabion (Germany) are listed in table (1).

\section{PCR amplification:}

Primers were utilized in a $25-\mu 1$ reaction containing $12.5 \mu \mathrm{l}$ of EmeraldAmp Max PCR Master Mix (Takara, Japan), $1 \mu \mathrm{l}$ of each primer of $20 \mathrm{pmol}$ concentration, $4.5 \mu \mathrm{l}$ of water, and $6 \mu \mathrm{l}$ of DNA template. The reaction was performed in an Applied biosystem 2720 thermal cycler.

\section{Analysis of the PCR Products:}

The products of PCR were separated by electrophoresis on 1\% agarose gel (Applichem, 
Germany, GmbH) in 1x TBE buffer at room temperature using gradients of $5 \mathrm{~V} / \mathrm{cm}$. For gel analysis, $20 \mu \mathrm{l}$ of the products was loaded in each gel slot. Gelpilot100 bp and 100 bp plus Ladders (Qiagen, Germany, GmbH) and generuler 100 bp ladder (Fermentas, Germany) were used to determine the fragment sizes. The gel was photographed by a gel documentation system (Alpha Innotech, Biometra) and the data was analyzed through computer software.

Table 1: Primers sequences, target genes, amplicon sizes and cycling conditions used in PCR assayes for L. monocytogenes.

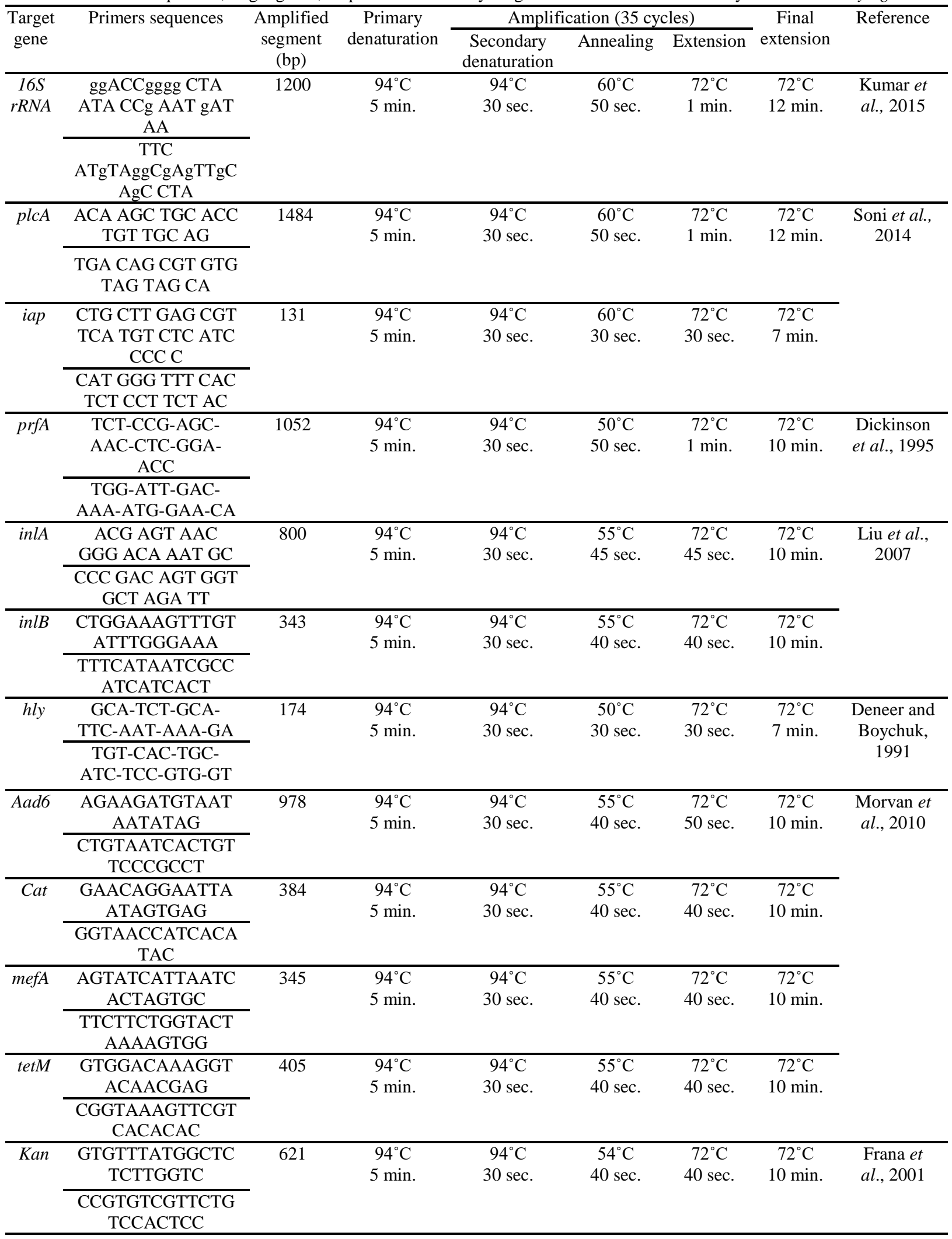




\section{RESULTS}

Table 2: Isolation rate of Listeria monocytogenes from some ready-to-eat chicken samples.

\begin{tabular}{cccc}
\hline Type of samples & No. of examined samples & \multicolumn{2}{c}{ Positive samples } \\
\cline { 3 - 4 } & & No. & \% \\
\hline Chicken Shawerma & 25 & 2 & 8 \\
\hline Chicken Burger & 25 & 1 & 4 \\
\hline Chicken breast fillet & 25 & 1 & 4 \\
\hline Total & 75 & 4 & 5.3 \\
\hline
\end{tabular}

Table 3: PCR results of the specific gene and different virulence genes of isolated Listeria monocytogenes

\begin{tabular}{|c|c|c|c|c|c|c|c|}
\hline \multirow{2}{*}{$\begin{array}{l}\text { No. of isolated } \\
\text { listeria } \\
\text { monocytogenes }\end{array}$} & \multirow{2}{*}{$\begin{array}{c}\text { listeria monocytogenes } \\
\text { specific gene } \\
\text { I6S rRNA gene }\end{array}$} & \multicolumn{6}{|c|}{ listeria monocytogenes virulence genes } \\
\hline & & inlA & inlB & hly & iap & plcA & prfA \\
\hline 1 & + & + & + & - & - & - & - \\
\hline 2 & + & + & + & - & - & - & - \\
\hline 3 & + & + & + & - & - & - & - \\
\hline 4 & + & + & + & - & - & - & - \\
\hline Positive \% & 100 & 100 & 100 & $\mathbf{0}$ & $\mathbf{0}$ & $\mathbf{0}$ & $\mathbf{0}$ \\
\hline
\end{tabular}

inlA gene (internalin A gene)

inlB gene (internalin B gene)

hly gene (listeriolysin $\mathrm{O}$ gene)

iap gene (invasion- associated protein)

$p l c A$ gene (Phospholipase gene)

prfA gene (Pleiotropic regulatory factor)

Table 4: PCR results of resistance genes of isolated Listeria monocytogenes

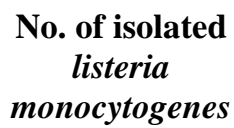

listeria monocytogenes resistance genes

\begin{tabular}{cccccc}
\cline { 2 - 5 } & mefA & Kan & Aad6 & tetM & Cat \\
\hline 1 & + & - & + & - & - \\
\hline 3 & + & - & + & + & - \\
\hline 4 & + & - & + & - & - \\
\hline Positive \% & + & - & 100 & 0 & 0 \\
\hline
\end{tabular}

mefA gene ( macrolides resistance gene)

Kan gene (Kanamycin resistance gene)

Aad6 gene (aminoglycosides resistance gene)

tet $M$ gene (tetracycline resistance gene)

Cat gene (chloramphenicol resistance gene) 


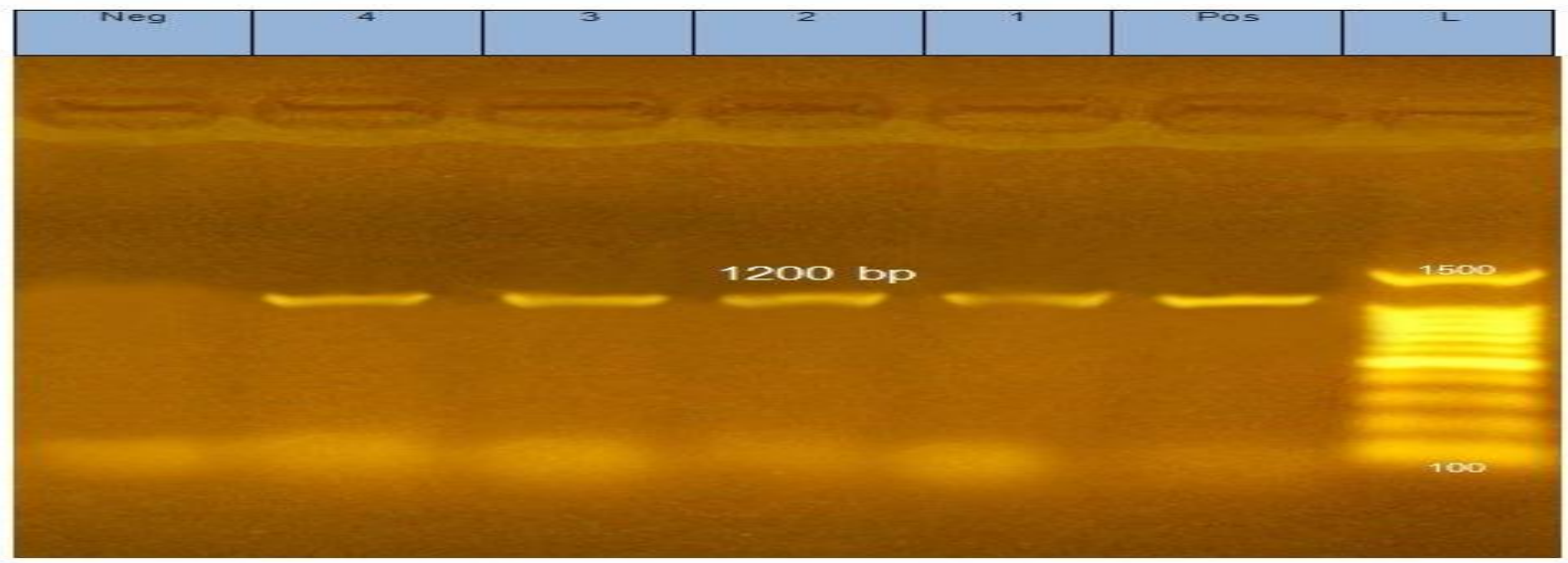

Figure 1: Agarose gel electrophoresis of PCR of $16 \mathrm{~S} r R N A$ gene (1200bp) in isolated Listeria monocytogenes.

Lane L : 100 -1500bp ladder as molecular size DNA marker.

Lane Pos: Control positive Listeria monocytogenes for $16 S$ rRNA gene.

Lane Neg.: Control negative Listeria monocytogenes for $16 \mathrm{~S}$ rRNA gene.

Lanes: $1-4$ are positive Listeria monocytogenes for $16 S$ rRNA gene.

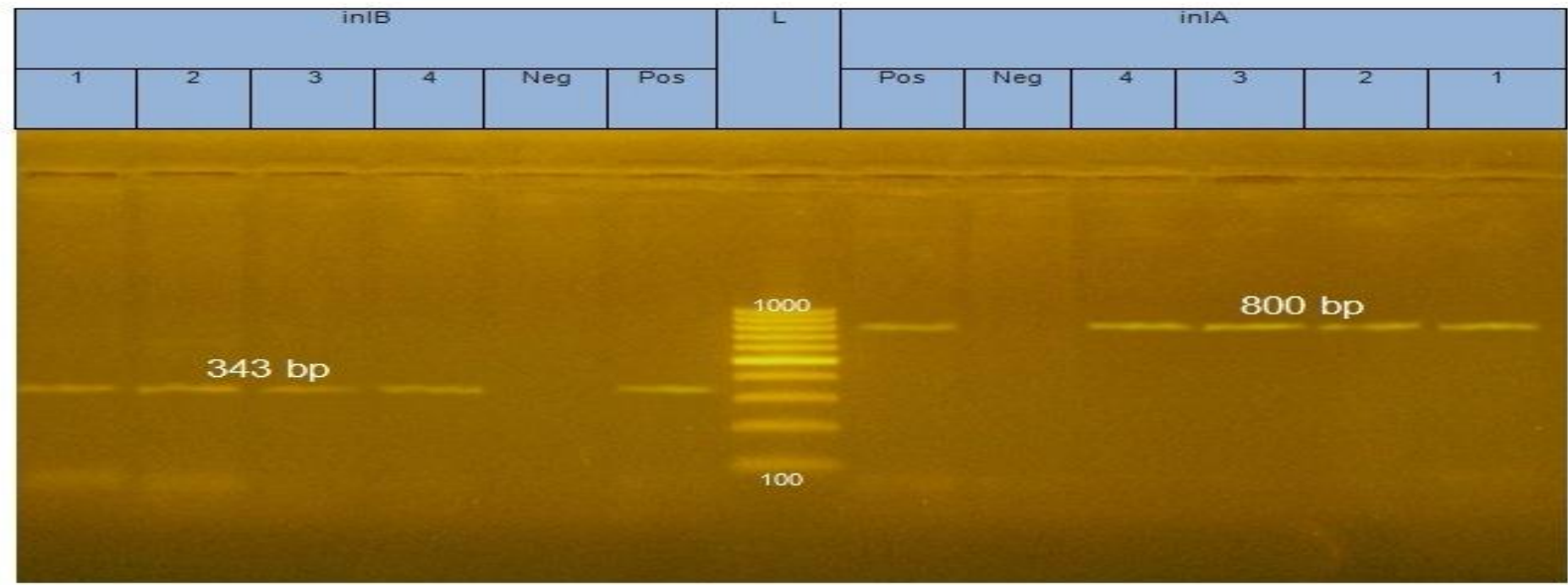

Figure 2: Agarose gel electrophoresis of PCR of inlB gene (343bp) and inlA gene (800bp) in isolated Listeria monocytogenes.

Lane L : 100 -1000bp ladder as molecular size DNA marker.

Lane Pos: Control positive Listeria monocytogenes for inlB gene and inlA gene.

Lane Neg.: Control negative Listeria monocytogenes for inlB gene and inlA gene.

Lanes: $1-4$ are positive Listeria monocytogenes for inlB gene and inlA gene.

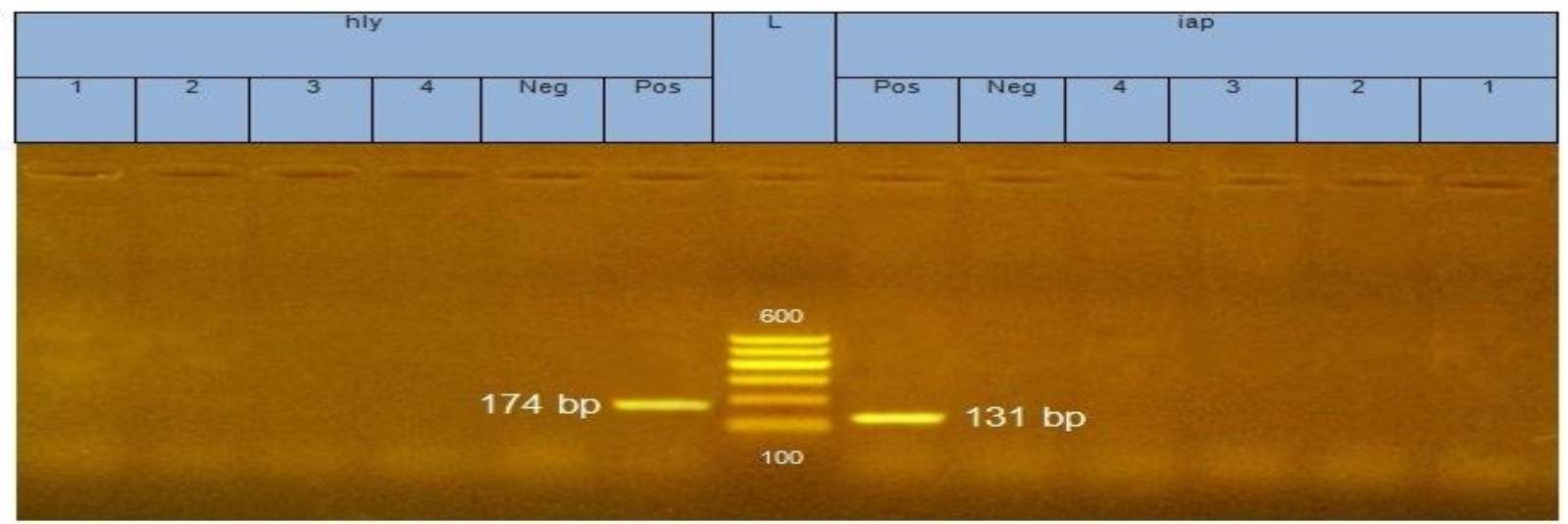

Figure 3: Agarose gel electrophoresis of PCR of hly gene (174bp) and iap gene (131bp) in isolated Listeria monocytogenes.

Lane L : 100 -600bp ladder as molecular size DNA marker.

Lane Pos: Control positive Listeria monocytogenes for hly gene and iap gene.

Lane Neg.: Control negative Listeria monocytogenes for hly gene and iap gene

Lanes: $1-4$ are negative Listeria monocytogenes for hly gene and iap gene. 


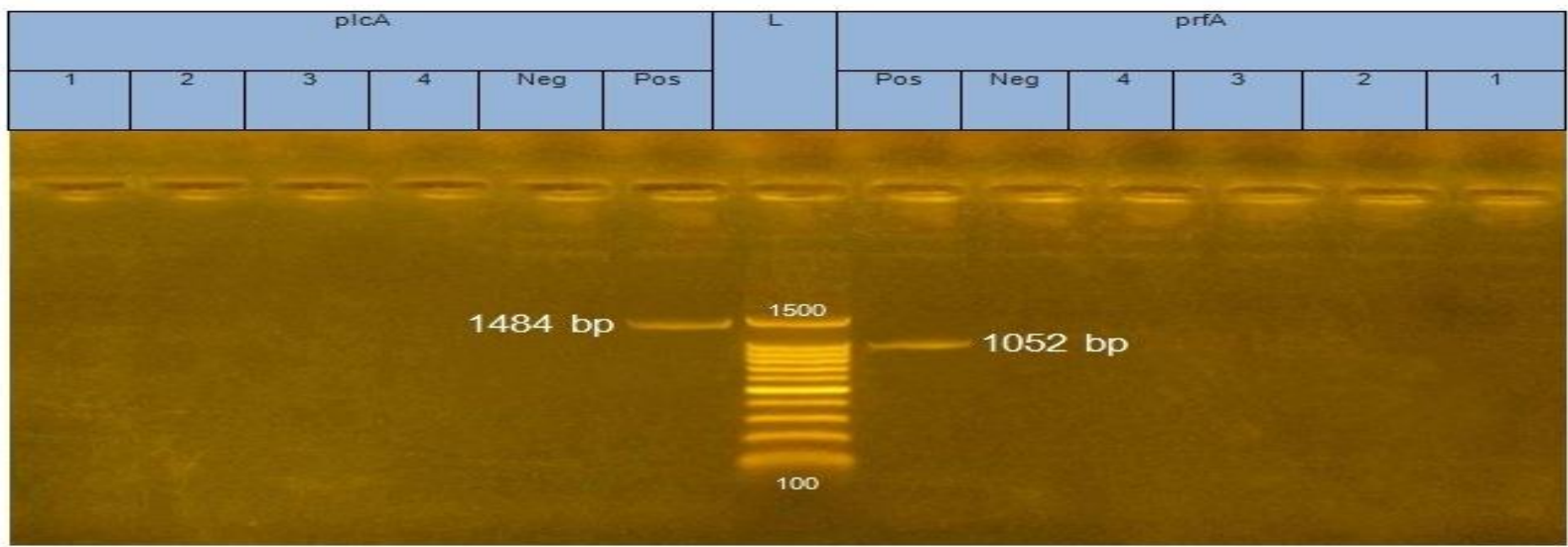

Figure 4: Agarose gel electrophoresis of PCR of plcA gene (1484bp) and prfA gene (1052bp) in isolated Listeria monocytogenes.

Lane $\mathbf{L} \quad$ : 100 -1500bp ladder as molecular size DNA marker.

Lane Pos: Control positive Listeria monocytogenes for plcA gene and prfA gene.

Lane Neg.: Control negative Listeria monocytogenes for $p l c A$ gene and prfA gene.

Lanes: $1-4$ are negative Listeria monocytogenes for plcA gene and prfA gene.

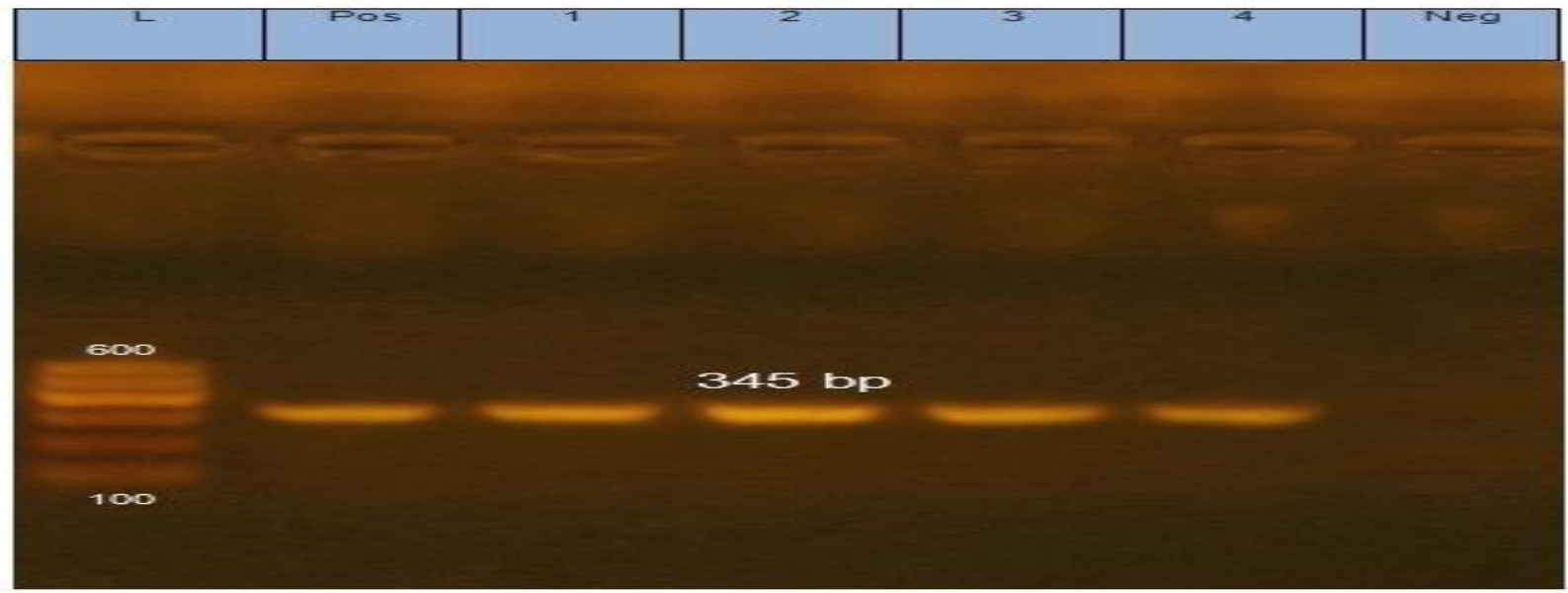

Figure 5: Agarose gel electrophoresis of PCR of mefA gene (345bp) in isolated Listeria monocytogenes.

Lane L : 100 -600bp ladder as molecular size DNA marker.

Lane Pos: Control positive Listeria monocytogenes for mefA gene.

Lane Neg.: Control negative Listeria monocytogenes for mefA gene.

Lanes: $1-4$ are positive Listeria monocytogenes for mefA gene.

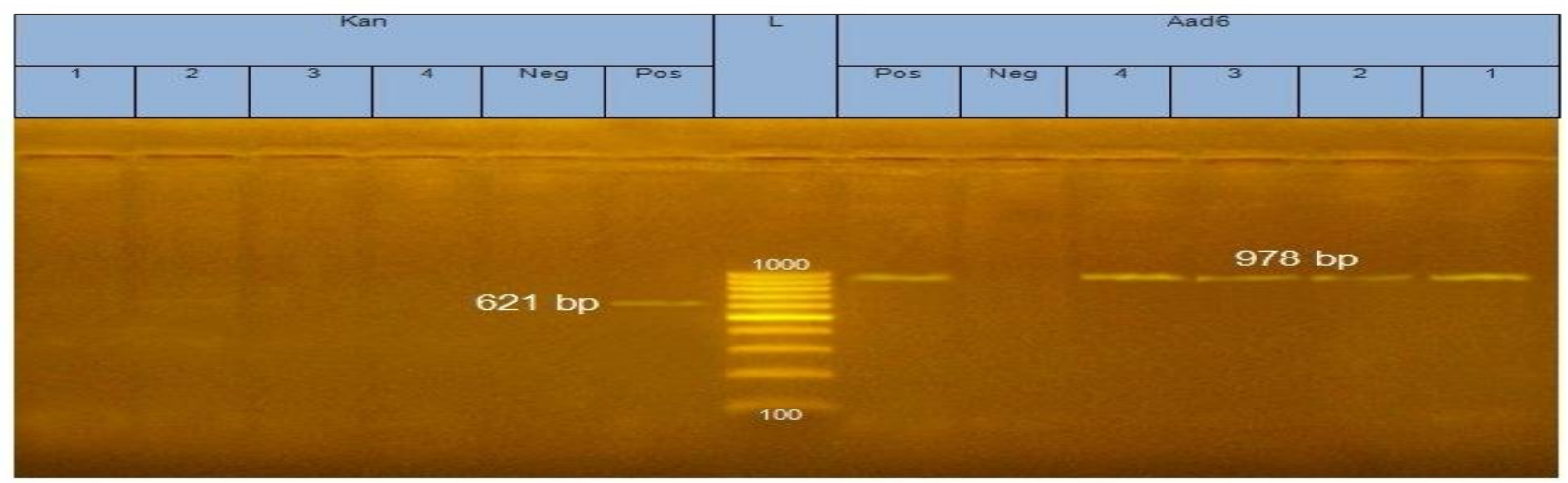

Figure 6: Agarose gel electrophoresis of PCR of Kan gene (621bp) and Aad6gene (978bp) in isolated Listeria monocytogenes.

Lane L : 100 -1000bp ladder as molecular size DNA marker.

Lane Pos: Control positive Listeria monocytogenes for Kan gene and Aad6 gene.

Lane Neg.: Control negative Listeria monocytogenes for Kan gene and Aad6 gene.

Lanes: Left 1-4 are negative Listeria monocytogenes for Kan gene \& Right 1-4 are positive Listeria monocytogenes for Aad6 gene. 


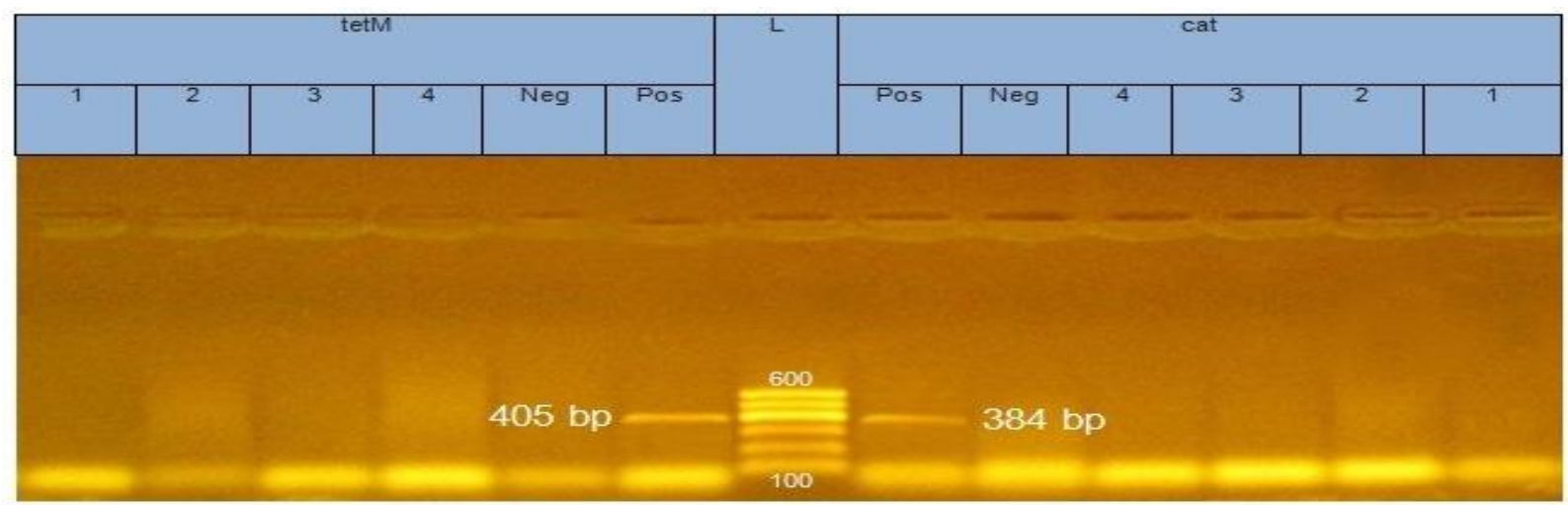

Figure 7: Agarose gel electrophoresis of PCR of tetM gene (405bp) and Cat gene (384bp) in isolated Listeria monocytogenes.

Lane L : 100 -600bp ladder as molecular size DNA marker.

Lane Pos: Control positive Listeria monocytogenes for tetM gene and Cat gene.

Lane Neg.: Control negative Listeria monocytogenes for tetM gene and Cat gene.

Lanes: $1-4$ are negative Listeria monocytogenes for tetM gene and Cat gene.

\section{DISCUSSION}

L. monocytogenes has been recognized as one of the most serious emerging bacterial diseases during the last two decades that is transmitted through the consumption of contaminated foods (Nørrung, 2000). Results of the current study revealed that from the total of 75 ready-to-eat chicken samples 4 $(5.3 \%)$ were found to be contaminated with L. monocytogenes (Table 2). Our findings are consistent with the results obtained by Cabedo et al. (2008) who found L. monocytogenes in ready-to-eat foods at a range of $6.2 \%$ to $20.0 \%$, depending on the food products.

Interestingly, chicken shawerma samples showed higher isolation rates for L. monocytogenes (8\%). It is noteworthy that the high isolation rate of L. monocytogenes from chicken shawerma underscored the potential role that may be played by this product to convey $L$. monocytogenes to the human gut. However, a lower rate of contamination was obtained by Abd-El-Malek (2017) who detected L. monocytogenes in $1(2.9 \%)$ of chicken shawerma collected from different restaurants in Assiut city. Comparatively, Alsheikh et al. (2013) recorded slightly lower isolation rate $(4 \%)$ of L. monocytogenes in chicken shawerma samples purchased from restaurants in Khartoum state Sudan. Also, L. monocytogenes was isolated from $12(4 \%)$ of 301 chicken shawerma samples in Jordan (Osaili et al., 2014). On the other hand, higher records were reported by several investigators as Moustafa ElShenawy et al. (2011) who found L. monocytogenes in $3(12.5 \%)$ of 24 samples of street-vended RTE shawerma in Alexandria city. Moreover, In Amman, Jordan, Osaili et al. (2011) isolated L.monocytogenes from shawerma with percent $13.3 \%$ of samples. The contamination by
L. monocytogenes in RTE meat primarily occurs during slicing and packaging after cooking. In addition, cross-contamination between raw materials, equipments, utensils, humans could contribute to the spread of L. monocytogenes in food processing plants (Jemmi and Stephen, 2006).

Additionally, one chicken burger sample yielded L. monocytogenes $(4 \%)$. The contamination of RTE foods could be due to many factors. One of the possible factors is via cross-contamination after the foods were cooked. We could not rule out the possibility that the cooking process is not sufficient to inactive these tough bacteria. In a study done by Wong et al. (2011), L. monocytogenes was not detected after six minutes of cooking chicken burger patties, but it was detected after four minutes of cooking. Therefore, efficient cooking of burgers is very important to prevent food-borne illness from burgers that may be contaminated with L. monocytogenes.

With regard to RTE cooked chicken breast fillet, it is evident from the data presented in Tables 2 that one sample with an incidence of $4 \%$ were contaminated with L. monocytogenes. In contrast, higher prevalence rate $(24 \%)$ was recorded by Abd-ElMalek (2017). On the contrary, in a related study performed by Diaz-Lopez et al. (2011), the presence of L. monocytogenes from grilled chicken was not detected by culture or PCR.

The detection of L. monocytogenes by molecular methods is very specific. 4 L. monocytogenes strains isolated from RTE cooked chicken samples by conventional methods were similarly confirmed as L. monocytogenes by PCR (Table 3) \&Figure (1).

Results illustrated in Table 3 and Figure 2 revealed that all four $(100 \%)$ isolates of L. monocytogenes 
were found to harbor InlA and inlB genes. InlA and inlB genes are associated with internalization of L. monocytogenes into the host cells (Bierne and Cossart, 2002; Orsi et al., 2007). The presence of internalin genes (inlA and inlB) in our L. monocytogenes isolates indicates the potential health hazard should such contaminated RTE foods were consumed by immune-compromised individuals. hlyA gene was not detected in all L. monocytogenes isolates in the current study. The absence of hlyA may be explained by the occurrence of a specific evolutionary event that resulted in alteration of the profile of genes responsible for pathogenesis. A similar observation was made by Ndahi et al. (2014), in which of 12 L. monocytogenes isolates from raw and processed meat products, only one harbored the hlyA gene. Also iap gene, plcA gene and prfA gene were not detected in all L. monocytogenes isolates in the current study.

The data outlined in Table 4, Figure 5, Figure 6 and Figure 7 illustrated that all four $(100 \%)$ isolates of L. monocytogenes were found to harbor mefA gene (macrolides resistance gene) and Aad6 gene (aminoglycosides resistance gene). While, Kan gene (Kanamycin resistance gene), tetM gene (tetracycline resistance gene) and Cat gene (chloramphenicol resistance gene) couldn't detected in any examined strains. Regarding to the result of tet $M$ gene which cannot be detected in the present study was disagreed the results reported by Charpentier and Courvalin, (1999), Bertsch et al. (2014) and Escolar et al.(2017) who found this gene in $100 \%$ of tetracycline- resistant strains. On the other hand our results was agreed the results that was recorded by Terzi et al. (2015) who cited that Listeria Species have no resistance to Tetracycline phenotypically. Erythromycin is a member of Macrolides antibiotic groups, Macrolide resistance gene (mefA gene) which detected in the present study also detected by Granier et al. (2011) who found two genes for resistance for Erythromycin $\operatorname{erm}(B)$ and $\operatorname{erm}(C)$ in food and the environment in France. Moreover, this result was coincides with Anas et al. (2015) who reported that presence of resistance to erythromycin against Listeria monocytogenes isolated from raw and processed meat products phenotypically in Jordan.

Listeriosis in humans is frequently transmitted via food products; consequently antibiotic-resistant L. monocytogenes isolates can have important public health consequences, especially in developing countries where there is widespread and often uncontrolled use of antibiotics. Since antibiotic resistance in L. monocytogenes is mainly due to acquisition of mobile elements such as plasmids and conjugative transposons (Charpentier and Courvalin, 1999), it is realistic to anticipate increased observations of bacterial antibiotic resistance in the future.

\section{CONCLUSION}

This study represents the presence of potentially pathogenic $L$. monocytogenes in various RTE cooked chicken meat purchased from different restaurants in Assiut province, by the PCR technique using primers targeting six virulence genes. Among the genes detected by the primers used, internalin genes (inlA and inlB) was most frequently found in isolates. All L. monocytogenes isolates were found to harbor mefA gene (macrolides resistance gene) and Aad6 gene (aminoglycosides resistance gene). The data from this study should serve as motivation to develop guidelines in order to ensure the overall safety of raw and processed chicken meat products.

\section{REFERENCES}

Abd-El-Malek, A.M. (2017): Cooked poultry meat and products as a potential source of some food poisoning bacteria. IOSR J. Environ. Sci. Toxic. and Food Techn.,11(6):23-29.

Alsheikh, A.D.I.; Mohammed, G.E. and Abdalla, M.A. (2013): Isolation and identification of listeria monocytogenes from retail broiler chicken ready to eat meat products in Sudan. International Journal of Animal and Veterinary Advances 5(1): 9-14.

Anas A. Al-Nabulsia; Osailia, T.; Awada, A.; Amin N.; Olaimatb, A.; Shakera, R. and Holleyb, R. (2015): Occurrence and antibiotic susceptibility of Listeria monocytogenes isolated from raw and processed meat products in Amman, Jordan. Journal of Food, 13, (3), 346-352.

Bertsch, D.; Muelli, M.; Weller, M. Uruty, A. Lacroix, C. and LeoMeile, L. (2014): Antimicrobial susceptibility and antibiotic resistance gene transfer analysis of foodborne, clinical, and environmental Listeria spp. Isolates including Listeria monocytogenes. Microbiologyopen.3(1): 118-127.

Bierne, H. and Cossart, P. (2002): InlB, a surface protein of Listeria monocytogenes that behaves as an invasin and a growth factor. Journal of Cell Science, 115:3357-3367

Blum-Menezes, D.; Deliberalli, I.; Bittencourt, N.C.; do Couto, C.A.T.; Barbosa, L.N.; dos Santos, A.M. and Pinto, G.G. (2013): Listeriosis in the far South of Brazil: Neglected infection. Rev. Soc. Bras. Med. Trop., 46: 381-383.

Cabedo, L.; Picart, I.; Barrot, L.; Teixido', A. and Canelles, I. (2008): Prevalence of Listeria monocytogenes and Salmonella in ready- to- 
eat food in Catalonia, Spain. J. Food Prot., 71(4):855-859.

Charpentier, E. and Courvalin, P. (1999): Antibiotic resistance in Listeria spp. Antimicrobial Agents and Chemotherapy, 43, 2103-2108.

Chernak, E.D. and Sobel, J. (2006): Multistate outbreak of listeriosis linked to turkey deli meat and subsequent changes in US regulatory policy, Clin. Infect. Dis., 42: 2936.

Conter, M.; Paludi, D.; Zanardi, E.; Ghidini, S.; Vergara, A. and Ianieri, A. (2009): Characterization of antimicrobial resistance of foodborne Listeria monocytogenes. International Journal of Food Microbiology, 128:497-500.

Cooray, K.J.; Nishibori, T.; Xiong, H.; Matsuyama, T.; Fujita, M. and Mitsuyama, M. (1994): Detection of multiple virulence-associated genes of Listeria monocytogenes by PCR in artificially contaminated milk samples. Appl. Environ. Microbiol., 60: 3023-3026.

Deneer, H.G. and Boychuk, I. (1991): SpeciesSpecific Detection of Listeria monocytogenes by DNA Amplification. Appl. Environ. Microbiol.,: 606-609.

Díaz-López, A.; Cantú-Ramírez, R.C.; GarzaGonzález, E.; Ruiz-Tolentino, L.; Tellez-Luis, S.J.; Rivera, G. and Bocanegra-García, V. (2011): Prevalence of foodborne pathogens in grilled chicken from street vendors and retail outlets in Reynosa, Tamaulipas, Mexico. J. Food Prot., 74(8):1320-3.

Dickinson, J.H.; Kroll, R.G. and Grant, K.A. (1995): The direct application of the polymerase chain reaction to DNA extracted from foods. Letters in Applied Microbiology, 20: 212216.

[EFSA] European Food Safety Authority (2015): The Community Union summary report on trends and sources of zoonoses and zoonotic agents in European Union. EFSA, J.; 13: 4329.

Escolar, C.; Gomez, D.; Mar'la del Carmen Rota Garcia, Conchello, $P$. and Herrera, A. (2017): Antimicrobial resistance profiles of Listeria monocytogenes and Listeria innocua isolated from ready-to-eat products of animal origin in Spain. Foodborne pathogens and disease, 14(6): 357-363.

FAO/WHO. (2004): Microbiological risk assessment series (5): Risk assessment of Listeria monocytogenes in ready-to-eat food (Technical Report). Available from: http:// www.fao.org/3/a-y5394e.pdf.

Frana, T. S.; Carlson, S.A. and Griffith, R.W. (2001): Relative distribution and conservation of genes encoding aminoglycoside-modifying enzymes in Salmonella enterica serotype Typhimurium phage type DT104. Appl. Environ. Microbiol., 67: 445-448.

Furrer, B.; Candrian, U.; Hoefelein, C. and Luethy, J. (1991): Detection and identification of Listeria monocytogenes in cooked sausage products and in milk by in vitro amplification of haemolysin gene fragments. J. Appl. Bacteriol., 70: 372-379.

Goulet, V.; Hedberg, C.; Le Monnier, A. and De Valk, H. (2008): Increasing incidence of listeriosis in France and other European countries. Emerg. Infect. Dis., 14: 734-740.

Gómez, D.; Azón, E.; Marco, N.; Carramiňana, J.J.; Rota, C.; Ariňo, A. and Yangũela, J. (2014): Antimicrobial resistance of Listeria monocytogenes and Listeria innocua from meat products and meat processing environment. Food Microbiol., 42 :61-65.

Gottlieb, S.L.; Newbern, E.C.; Griffin, P.M.; Graves, L.M.; Hoekstra, R.M.; Baker, N.L.; Hunter, S.B.; Holt K.G.; Ramsey, F.; Head, M.; Levine, P.; Johnson, G.; SchoonmakerBopp, D.; Reddy, V.; Kornstein, L.; Gerwel, M.; Nsubuga, J.; Edwards, L.; Stonecipher S.; Hurd, S.; Austin, D.; Jefferson, M.A.; Young, S.D.; Hise, K.; Gusman V.; Medić D.; Jelesić Z.; Mihajlović-Ukropina M.; Milošević $V$. and Považan A. (2006): Multistate outbreak of listeriosis linked to turkey deli meat and subsequent changes in US regulatory policy. Clin. Infect. Dis., 42: 29-36.

Granier, S.A.; Moubareck, C.; Colaneri, C.; Lemire, A.; Roussel, S.; Dao, T.T.; Courvalin, P. and Brisabois, A. (2011): Antimicrobial resistance of Listeria monocytogenes isolates from food and the environment in France over a 10-year period. Appl. Environ. Microbiol.; 77 :2788-2790.

Gusman, V.; Medić, D.; Jelesić, Z.; MihajlovićUkropina, M.; Milošević, V. and Považan, A. (2014): Listeria monocytogenes isolated in ready-to-eat food in South Bačka region of Vojvodina province, Serbia. Arch. Biol. Sci.Belgrade, 66: 11-14.

Harakeh, S.; Saleh, I.; Zouhairi, O.; Baydoun, E.; Barbour, E. and Alwan, N. (2009): Antimicrobial resistance of Listeria monocytogenes isolated from dairy-based food products. Science of the Total Environment, 407:4022-4027.

(ISO 11290-1) International Organization for Standarization (2017): Microbiology of the food chain - Horizontal method for the detection and enumeration of Listeria monocytogenes and of Listeria spp. - Part 1: Detection method. International Standard ISO 11290-1. Geneva, Switzerland: International Organization for Standarization. 
Jemmi, T. and Stephen, R. (2006): Listeria monocytogenes: Food-borne pathogen and hygiene indicator. "Revue scientifique et technique (International Office of Epizootics)" (Journal) 25: 571-580.

Jeyasekaran, G.; Karunasagar, I. and Karunasagar, I. (1996): Incidence of Listeria spp. In tropical fish. Int. J. Food Microbiol., 31: 333 340.

Kumar, A.; Grover, S. and Batish, V.K. (2015): Exploring specific primers targeted against different genes for a multiplex PCR for detection of Listeria monocytogenes. 3 Biotech, 5:261-269.

Lianou, A. and Sofos, J.N. (2007): A review of the incidence and transmission of Listeria monocytogenes in ready-to-eat products in retail and food service environment. J. Food Prot., 70: 21722198.

Liu, D.; Lawrence, M.L.; Austin, F.W. and Ainsworth, A.J. (2007): A multiplex PCR for species- and virulence-specific determination of Listeria monocytogenes. Journal of Microbiological Methods, 71:133-140.

Morvan, A.; Moubareck, C.; Leclercq, A.; HervéBazin, M.; Bremont, S.; Lecuit, M.; Courvalin, P. and Le Monnier, A. (2010): Antimicrobial Resistance of Listeria monocytogenes Strains Isolated from Humans in France. Antimicrobial Agents and Chemotherapy, 54 (6): 2728-2731.

Moustafa El-Shenawy, Mohamed El-Shenawy, Jordi Mañes, and Jose M. Soriano (2011): Listeria spp. in Street-Vended Ready-to- Eat Foods. Interdisciplinary Perspectives on Infectious Diseases, 2011:1-6.

Ndahi, M.D.; Kwaga, J.K.P.; Bello, M.; Kabir, J.; Umoh, V.J.; Yakubu, S.E. and Nok, A.J. (2014): Prevalence and antimicrobial susceptibility of Listeria monocytogenes and methicillin-resistant Staphylococcus aureus strains from raw meat and meat products in Zaria, Nigeria. Letters in Applied Microbiology, 58 (3): 262-269.

Nishibori, T.; Cooray, K.; Xiong, H.; Kawamuru, I.; Fujita, M. and Mitsuyama, M. (1995): Correlation between the presence of virulence associated genes as determined by PCR and actual virulence to mice in various strains of Listeria spp. Microbiol Immunol.,39: 343349.

Nørrung, B. (2000): Microbiological criteria for L. monocytogenes in foods under special consideration of risk assessment approaches. Int. J. Food Microbiol., 62: 217-221.

Orsi, R.; Ripoll, D.; Yeung, M.; Nightingale, K. and Wiedmann, M. (2007): Recombination and positive selection contribute to evolution of Listeria monocytogenes inlA. Microbiology, 153: 2666-2678.

Osaili, T.M.; Alaboudi, A.R. and Nesiar, E.A. (2011): Prevalence of Listeria spp. and antibiotic susceptibility of Listeria monocytogenes isolated from raw chicken and ready-to-eat chicken products in Jordan. Food Control, 22: 586-590.

Osaili, T.M.; Al-Nabulsi, A.A.; Shaker, R.R.; Jaradat, Z.W.; Taha, M.; Al-Kherasha, M.; Meherat, M. and Holley, R. (2014): Prevalence of Salmonella serovars, Listeria monocytogenes, and Escherichia coli O157: $\mathrm{H} 7$ in Mediterranean ready-to-eat meat products in Jordan. J. Food Prot., 77:106111.

Portnoy, D.A.; Ghakraborty, T.; Goebel, W. and Cossart, P. (1992): Molecular determinants of Listeria monocytogenes pathogenesis. Infect. Immun., 60: 1263-1267.

Poyart-Salmeron, C. (1990): Transferable plasmidmediated antibiotic resistance in Listeria monocytogenes. The Lancet, 335: 14221426.

Soni, D.K.; Singh, M.; Singh, D.V. and Dubey, S.K. (2014): Virulence and genotypic characterization of Listeria monocytogenes isolated from vegetable and soil samples. BMC Microbiology, 14:241.

Swaminathan, B. (2001): Listeria monocytogenes. In: Doyle, M.P.; Beuchat, L.R. and Montville, TJ. editors. Food Microbiology. Food Fundamentals and Frontiers. American Society for Microbiology, Washington D.C., USA. :383-409.

Terzi, G.; Gucukogiu, A.; Cadirct, O.; Uyanik, T. and Alisarli, M. (2015): Serotyping and antibiotics susceptibility of Listeria monocytogenes isolated from resdy to eat foods in Samsun, Turkey. Turk. J. Vet. Sci. 39: 211-217.

Wagner, M.; Melzner, D.; Bago, Z.; Winter, P.; Egerbacher, M.; Schilcher, F.; Zangana, A. and Schoder, D. (2005): Outbreak of listeriosis in sheep: Evaluation from possible contamination routes from feed to raw produce and humans. J. Vet. Med., 52: 278283.

Wong, W.C.; Pui, C.F.; Chilek, T.Z.T.; Noorlis, A.; Tang, J.Y.H.; Nakaguchi, Y.; Nishibuchi, M. and Radu, S. (2011): Survival of Listeria monocytogenes during frying of chicken burger patties. Food Nutr. Sci., 2: 471-475. 


\section{جينات الضر اوة لميكروب الليستيريا مونوسيتوجينز المعزول من بعض وجبات الاجاج الجاهزه للاستهلاك سهيلة فتحى حسن الهوارى , محمد حمدى محمد ، سبإ حسن أحد الهبتى}

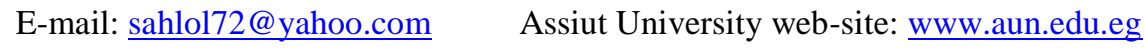

أجريت هذه الدر اسة على هل عينه من وجبات الدجاج الجاهزه للاكل بو اقع خمس و عشرين عينة من كل من (شاور مدهـ- برجر - بانيه)

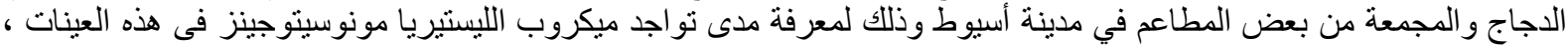

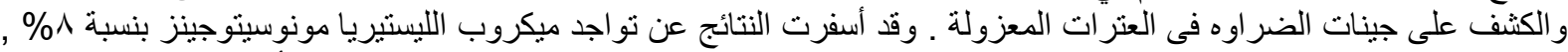

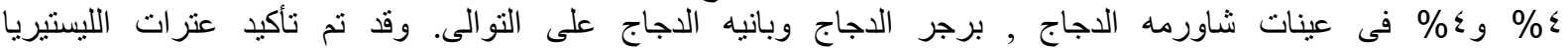
مونوسينوجينز المعزوله بإستخدام تقنية تفاعل إنزيم البلمرة المنسلسل للكثف عن إن وجن وجود جين

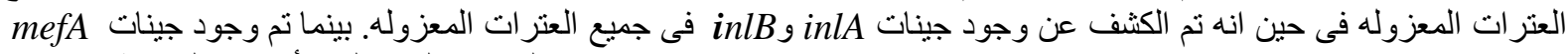

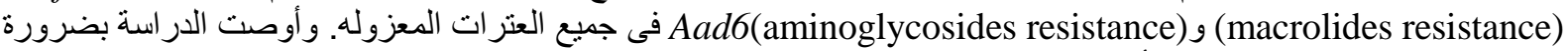
تطبيق الاشتراطات الصحية الجيده أثناء عمليات اعداد وتجهيز وجبات الاجاج لتقليل تلوثها بميكروب الليستيريا مونوسيتوجينز. 